\title{
O TEATRO COMPARADO sartre leitor dos clássicos
}

\section{Deise Quintiliano Pereira}

\begin{abstract}
RESUMO
Leitura semiológica de um episódio da peça do escritorfilósofo Jean-Paul Sartre, Les mouches, baseada no método comparativo, buscando estabelecer relaçōes entre a versāo sartriana do mito de referência grego, de Orestes e Electra, e as desenvolvidas pelos tragediógrafos gregos, do séc. $V$ a.C., Sófocles, Ésquilo e Eurípedes. Através deste confronto, será analisada a originalidade da versão de Sartre, trans. formada em funçāo do momento sócio-histórico-político contemporâneo e da filosofia existencialista.
\end{abstract}

\author{
PALAVRAS - CHAVE \\ teatro sartriano, tragédia, mito grego
}

INTRODUÇĀO

presente estudo tem por objetivo propor uma análise semiológica aplicada a um dos episódios de Les mouches (Sartre, 1943), primeira peça do escritor-filósofo Jean-Paul Sartre, publicada em 1943. Este ano é marcado também pelo aparecimento de Lêtre et le néant, tratado ontológico que sistematiza o pensamento filosófico de Sartre. No seu universo da dramaturgia, inscrevem-se outras peças, quais Huis clos (1944), Morts sans sépulture (1947), Les mains sales (1948), Le diable et le bon dieu (1951), por exemplo, que, assim como Les mouches, seguem um esquema básico, pertinente a todas as peças sartrianas - o estabelecimento de um problema moral, do qual os personagens não conseguem escapar, resultando ações conseqüentes de tentativas de se chegar a uma solução.

O teatro de Sartre retoma, então, a concepção de pièce à thèse, à medida que o drama é veículo para a divulgação de idéias filosóficas, com propósito didático, à maneira voltairiana. Por este método, Sartre atinge diretamente um vasto público, exigência de uma literatura engajada, provocando o julgamento crítico do espectador que, identificado com os problemas postos em cena, é levado a transcender o caráter particular da história e a refletir sobre as soluções fornecidas pelo viés da filosofia.

Não ocorre, entretanto, na dramaturgia sartriana, ruptura brusca de estrutura ou mesmo renovação de formas, capazes de reverter as regras do tradicional jogo teatral. Interessa a Sartre, sobretudo, extrair da encenação efeitos que se prestem a um propósito claro de revelar uma preocupação ética ou ideológica, a serviço da qual sua produção literária se coloca. 
Embora na conclusão de La nausée (1938), Sartre tenha reafirmado o primado da arte, em particular da literatura, como valor passível de superar os limites definidos pelo absurdo da existência, a experiência da guerra reorienta sua direção, justificando o engajamento e fazendo com que ele se volte para os acontecimentos históricos, em detrimento de uma maior preocupação estética.

O século XX assiste a um movimento de renovação geral dos mitos, do qual Sartre participa com a publicação de Les mouches, a exemplo do que propõem outros autores com suas peças míticas, como Giraudoux: Amphitryon 38 (1929), La guerre de Troie n'aura pas lieu (1935), Sodome et Gomorrhe (1943) ou Jean Anouilh: Eurydice (1941), Antigone (1946), Médée (1953).

Em sua peça, Sartre re-lê o mito de Orestes e Electra, de acordo com sua visão existencialista do mundo. Outros autores, partindo das versões propostas pelos tragediógrafos gregos do século V a.C. - Sófocles, Eurípedes e Ésquilo - servem-se do mesmo argumento como pré-texto para dotar o mito antigo de nova significação. É o que se observa em Giraudoux, Électre (1937); Anouilh, Tu étais si gentil quand tu étais petit (1972); T. S. Eliot, La Réunion de famille (1952); dentre outros.

Trata-se, então, de um mito acolhido pela tragédia clássica e recuperado em nossa época, onde a essência trágica ainda reside. $O$ mito, entretanto, deve ser compreendido em sua totalidade, como o somatório de todas as suas variantes, inclusive as modernas, pois cada uma delas reflete um questionamento profundo sobre os problemas fundamentais para a condição humana, origem do seu vigor sempre atual.

A tragédia grega acolhe bem o mito pois, como ele, é definida antes e sobretudo pela natureza das questões que apresenta, mais do que pelas respostas que fornece. Alimentando-se da experiência contemporânea, mas elevando-se acima do contemporâneo, a tragédia "pode tocar qualquer um em qualquer época". ${ }^{1}$ Este fato explica, talvez, a discussão que se ergue em torno de uma possível ressurreição da tragédia, na contemporaneidade. O homem moderno, segundo Camus, ${ }^{2}$ vive num clima trágico. Ele é um herói solitário, em eterno confronto consigo mesmo.

Baseando-se neste fato, Sartre estabelecerá a oposição entre tragédia da fatalidade e tragédia da liberdade, cujos sentidos serão desvelados a partir da confrontação da peça com sua referência obrigatória: o mito grego de Orestes e Electra, concebido nas versões dos citados tragediógrafos. A originalidade da peça sartriana resulta da presença atuante de outros dois discursos: o pensamento filosófico de Sartre fundado no existencialismo - e o momento histórico contemporâneo à sua publicação - a França sob ocupaçāo alemã.

O método a ser utilizado é o comparativo, que permitirá, através do diálogo intertextual travado com os discursos que compõem o tecido de Les mouches, ressaltar o que a peça de Sartre propóe de inédito. Da idéia de tecido, depreende-se a de texto, no sentido em que Barthes os faz equivaler: a partir de um entrelaçamento perpétuo que se perde nesta textura, à qual o leitor também se integra num jogo de velar e desvelar sentidos.

\footnotetext{
${ }^{1}$ Romilly. La tragédie grecque, p. 167.

${ }^{2}$ Camus. Conférence prononcée à Athènes sur l'avenir de la tragédie, p.1707.
} 
Todos esses pontos constituem premissas que viabilizarão a leitura de um episódio de Les mouches, como uma possibilidade a mais de participar do texto, fazendo aflorar, pelo processo gerativo que atua no binômio escritura-leitura, os seus inter-ditos.

O TECIDO DE LES MOUCHES

A peça de Sartre, Les mouches, insere-se num conjunto mais amplo de variantes que compōem o mito grego de Electra e Orestes. Sartre concretiza, neste texto, princípios básicos do seu pensamento filosófico. Contudo, o escritor não nos propōe, com Les mouches, uma tragédia à antiga, mas uma representação do trágico moderno: "Eu quis [dizia Sartre, apresentando Les mouches] tratar da tragédia da liberdade em oposição à tragédia da fatalidade". 3

Com esta afirmação, Sartre parece identificar sua proposta de retomada do mito baseada na reflexão individual e racionalista, segundo pólo da dicotomia estabelecida por Camus, que reconhece na história da humanidade dois grandes momentos trágicos. O primeiro seria marcado por formas do pensamento cósmico, impregnadas pela noção do divino e do sagrado, que Sartre não se dispõe a recuperar.

Uma análise semiológica da peça aponta para confluência de vários textos na textura de Les mouches. Desses, que interagem decisivamente na produção da peça sartriana, alguns, fundamentais, necessitam ser privilegiados. Sāo eles:

a) O mito grego de Electra/Orestes - a renovação dos mitos no século XX.

b) $O$ pensamento filosófico sartriano - a tragédia da liberdade.

c) O contexto histórico (a França durante a 2a Guerra) - a luta contra a opressāo.

A seguir, iniciamos a abordagem desses textos referenciais, que traçam como que o risco do bordado no tecido de Les mouches.

\section{O mito grego de Electra/Orestes}

Ao abordar o mito de referência grego de Electra e Orestes, a partir do que propõe a trilogia de Ésquilo, Oréstia, e as versões de Sófocles e Eurípedes, nas peças intituladas Electra, é imperativo que se elucidem determinados fatos, que antecederam a "açāo" / "trama", expressos nas referidas tragédias, dos quais a "maldição dos Atridas" constitui um dado significativo.

A "maldição dos Atridas" remonta ao episódio do cocheiro de Enomaô, Mírtilo, que, segundo a lenda, teria sabotado a charrete de seu mestre, numa corrida que este empreendera com Pélops, pretendente à mão de sua filha (de Enomaô), Hipodamia. Sem a ajuda do cocheiro, Pélops jamais venceria Enomaô, uma vez que os cavalos deste eram divinos. Após a vitória, Mírtilo foi jogado ao mar por Pélops, tendo, ao morrer, amaldiçoado sua raça. Pélops teve dez filhos, dentre os quais Tiestes e Atreu, que se odiavam. Tiestes cometera adultério com sua cunhada Aérope e Atreu, como modo de vingança, matou os filhos de Tiestes, que foram cortados em pedacinhos e servidos ao pai num banquete macabro, como carne de animal.

Daí o ódio de Egisto, único filho sobrevivente de Tiestes, para com os filhos de Atreu: Agamemnon, rei de Micenas e Argos, e Menelau, rei de Esparta. Os dois

\footnotetext{
${ }^{3}$ SARTRE citado por DOMENACH. Le retour du tragique, p.29.
} 
desposaram duas irmãs: Clitemnestra e Helena, filhas de Tíndaro e Leda. Clitemnestra fora casada com Tântalo II, filho de Tiestes, mas Agamemnon matou Tântalo assim como o recém-nascido filho do casal. Clitemnestra o desposa, porém a contragosto. Helena foi raptada por Páris ou Alexandre, filho de Príamo, rei de Tróia, instaurando assim a célebre guerra.

A deusa Artemis, entretanto, enfurecida com a soberba de Agamemnon, que, ao matar uma corça, teria proclamado que a própria deusa não faria melhor, nāo envia ventos favoráveis à navegação, impedindo a partida da esquadra aquéia do porto de Aulis. Contudo, a versão para a ira da deusa oferecida pela peça Agamemnon, de Ésquilo, apresenta-se sob a forma de um presságio guerreiro. Duas águias com seus filhotes devoram uma lebre prenhe. O adivinho do exército reconhece nesses devoradores de lebres os dois guerreiros atridas, Agamemnon e Menelau, de igual querer, que deveriam apoderar-se da cidade de Príamo. A deusa, irritada por terem os "cães alados" do pai imolado a pobre lebre antes que essa desse à luz, exige o sacrifício de Ifigênia, sob pena de não enviar ventos favoráveis às naus atridas. Agamemnon sacrifica então à deusa sua filha, arrancando-a dos braços da mãe, Clitemnestra. Esta torna-se amante de Egisto durante a guerra, engendrando, assim, a vingança contra o marido.

Quando Agamemnon volta vitorioso de Tróia, após dez anos de combate, traz consigo Cassandra, a profetiza filha de Príamo, por quem se apaixonara. Clitemnestra e Egisto matam ambos no palácio dos Atridas, onde passam a reinar. A partir de então, a filha, Electra, vive como escrava, enquanto o filho, Orestes, é enviado para a Fócida. Anos mais tarde, Electra e Orestes, que volta do exílio, vingam a morte do pai, matando Clitemnestra e Egisto.

De todas essas informações que compōem o curso da "maldição dos Atridas", o dado mais significativo parece constituir-se no assassinato de Agamemnon sem punição. Penúltimo episódio da referida maldição, o assassinato exerce nítida função de tela de fundo das três peças já mencionadas, "pré-texto" daquela de Sartre, Les mouches. Voltemos a ele.

Ao retornar vitorioso a Argos, Agamemnon é recebido por Clitemnestra com hipócritas manifestaçōes de alegria. O rei é obrigado a passar por um tapete de púrpura, honra reservada aos deuses. Cassandra, que o acompanha, profetiza sua própria morte e a do rei atrida. De fato, tão logo penetra no palácio, Agamemnon é imolado pela esposa e seu amante.

Envolto numa rede sem saída, como a dos peixes, um rico tecido traiçoeiro, recebe dois golpes de espada desfechados por Clitemnestra. Ela lhe aplica ainda um terceiro, como oferenda votiva ao Zeus salvador dos mortos, que reina debaixo da terra. $\mathrm{Na}$ rede da morte enredam-se também os sentidos da trama.

\section{Estruturaçāo EPISÓdICA Na tRagédia grega}

A partir de cinco momentos significativos, que compõem a espinha dorsal do mito de referência grego: o assassinato de Agamemnon sem punição; a espera de Electra; o retorno de Orestes; o reconhecimento entre irmãos; o duplo crime; privilegiaremos, na versão de Ésquilo, As Coéforas, o último episódio, visando estabelecer 
convergências e divergências entre a peça grega e a sartriana. Na análise deste episódio específico - o duplo crime: assassinato de Clitemnestra e Egisto - buscaremos, pela comparação, elucidar a originalidade da peça sartriana, objeto deste estudo.

\section{$\mathrm{O}$ assassinato de Agamemnon sem punição}

A cena se passa na cidade de Argos diante do túmulo de Agamemnon. Há uma situação de carência: o assassinato sem punição. A cidade vive envolta em trevas, como numa longa noite. O Coro lembra que há um Destino a ser cumprido, dando prosseguimento à maldição dos Atridas. Devido ao temor de sonhos premonitórios, (proclamando que os mortos enfureciam-se contra seus assassinos), Clitemnestra designa Electra como mensageira de libações a Agamemnon. Tenta, assim, afastar a maldição com uma homenagem. Electra pede ajuda ao Coro. Este é de importância fundamental em Ésquilo, constituindo o próprio título da peça: "Coéforas" - moças que trazem libações.

\section{A espera de Electra}

Electra, tratada pelos atuais reis como escrava, é apresentada como um personagem em eterna expectativa. Espera o retorno do irmão, banido no passado pelos reis assassinos, para vingar a morte do pai. É o Corifeu quem, diante das hesitações de Electra, comanda suas açōes, evocando a "lei do talião". Electra espera o libertador (Orestes), encarnado na figura de um valente guerreiro: brandindo o arco dos Citas e a espada. É inexistente qualquer diálogo entre mãe e filha na versão esquiliana.

\section{$\mathrm{O}$ retorno de Orestes}

O retorno de Orestes, acompanhado de Pílades, acontece depois de longo exílio. É enviado por Lóxias que o ameaçara de castigos intoleráveis, como as lepras, se não cumprisse suas ordens: matar quem matou. Lóxias anunciara também furiosos ataques das Erínias, atraídas pelo sangue do pai. Orestes diz obedecer a Lóxias, à saudade do pai, à vontade de não deixar seus concidadãos ficarem servos de duas mulheres: Clitemnestra e Egisto - cujo coração também é de mulher. O Coro relembra a Orestes seguidamente seu papel de vingador. Orestes invoca Hermes subterrâneo e Zeus, nomeando-se agente da ação reparadora, quer mate ou morra.

\section{$\mathrm{O}$ reconhecimento entre os irmãos}

Orestes avista Electra caminhando em direção ao túmulo do pai e a reconhece por ela portar um luto amargo. Após ouvir o longo lamento da irmã, revela-lhe sua identidade. Esta é confirmada pela cor das madeixas, que ele próprio depositara sobre o túmulo, semelhante à dos cabelos de Electra. A marca deixada pelo calcanhar de Orestes, indicando contornos dos pés parecidos com os da irmã, e um tecido, outrora preparado pelas mãos da própria Electra, contendo cenas de caça, que Orestes lhe apresenta, confirmam sua identidade.

\section{O duplo crime}

O matricídio se prenuncia a partir dos pesadelos de Clitemnestra. Nesses sonhos tremendos, ela dava à luz uma serpente, que alimentava com o seu seio e que era ferido por este monstro. Misturava-se, assim, um coágulo de sangue ao seu leite. Orestes interpreta o seu papel como o da serpente que deseja o sangue da mãe, ou 
seja, sua morte. Disfarçado de estrangeiro, Orestes chega às portas externas do palácio, sempre acompanhado de Pílades - seu companheiro de armas. Finge, então, ser mensageiro de Estrófios, trazendo informações sobre Orestes que "está morto". O Corifeu pede à antiga ama de Orestes que chame Egisto. Este deve vir sem escolta para que a sentença se cumpra. O assassinato de Egisto não é descrito. Pílades lembra a Orestes, hesitante, os juramentos a Lóxias. Orestes penetra no palácio para executar o matricídio, que também não é descrito. O Corifeu anuncia a chegada da Justiça. Retorna a luz. Depois de um breve momento de alegria, chegam as Erínias. Orestes foge alucinado.

\section{O contexto histórico: a França durante a Segunda Guerra}

Para melhor compreender as significaçōes da peça Les mouches, não podem ser negligenciados os aspectos sócio-políticos nos quais a trama se insere; sobretudo a França sob ocupação alemã. Não é sem razão que Albérès define Sartre como o último escritor do entre-guerras e o primeiro escritor do pós-guerra, numa clara alusão à importância que o contexto histórico assume sobre a produção literária do autor, principalmente durante este período conturbado da vida nacional francesa. Interessanos, antes de mais nada, definir que reflexos este contexto exerceu sobre Les mouches, enquanto criação literária.

Historicamente, a partir de julho de 1940, defrontamo-nos com a situaçāo de uma França cindida entre zona livre e ocupada. O chamado "governo de Vichy" é creditado como responsável oficial pela continuidade do "Estado Francês", abolindo, por conseguinte, a República. Representando uma verdadeira monarquia sem monarca, o marechal Pétain, chefe de Estado e de governo, possui plenos poderes, tornando-se objeto de um verdadeiro culto e instaurando uma ditadura provisória. Sua adesão à causa alemã, por um lado representa o referendum de um marechal da França a uma política anti-nacional, desencadeando uma onda de propagandas pró-fascistas e derrotistas; por outro, auxilia a repressão contra os patriotas que desejavam ver a França novamente livre.

A contestação sindical, por sua vez, não é mais permitida que a contestação parlamentar. A linha geral é então a de uma contra-revolução deliberada e colaboracionista e Vichy "prolonga e agrava, em favor da presença do ocupante, a velha guerra civil francesa". ${ }^{4}$

Na zona ocupada, tendo ao centro Paris, há uma polarização: pode-se optar apenas entre ser colaborador ou patriota. Na chamada zona livre, com sede em Vichy, sem ocupante visível e com um governo francês, boa parte da direita clássica se reconhece. Outras tendências políticas (mais ingênuas) creditam a imobilidade a intenções verdadeiramente patrióticas de poupar luta e evitar o derramamento de sangue do povo. A adesão a Pétain cresce consideravelmente, assim como a repressão, que reelabora práticas de tortura já abolidas da história oficial há praticamente um século e meio.

Mas, como a toda ação corresponde uma reação, surge a Resistência francesa que se engaja na luta de libertação incitando os indivíduos a ações heróicas, muitas

\footnotetext{
${ }^{4}$ AgULHON. La France de 1940 à nos jours, p.7.
} 
vezes clandestinas ou aparentemente insignificantes, que dignificassem a condição do cidadão. Resistir poderia significar partir para Londres, onde o general de Gaulle, na condição de líder, articulava com a força britânica uma oposição às tropas alemãs. Resistir é também redigir e difundir folhas de propaganda que fornecem novas e verdadeiras informações sobre a guerra e polemizam contra Vichy. Resistir é participar de um esforço concentrado visando desentorpecer as mentes mergulhadas na aceitação passiva de um "mea culpa" que expiasse, através da convivência harmônica com os inimigos, a responsabilidade de todos os erros do passado, como propunha Pétain.

As artes de uma forma geral e a literatura de um modo específico vão interagir com esta situação, apoiando-se para tanto numa linguagem simbólica, que passasse despercebida aos radares implacáveis das forças nazi-fascistas. É neste contexto que Les mouches se situam.

Superado o individualismo céptico e após um período de prisão e Resistência a responsabilidade de tornar-se "homem entre os homens" ocupa o lugar da gratuidade do passado. Segundo Sartre, mais por uma questão de necessidade do que propriamente de vontade. Deste modo, ao lançar Les mouches, Sartre inicia-se na produção dramática.

$\mathrm{Na}$ peça, a sátira política e religiosa se imbricam. Isto dificulta parcialmente a compreensão maciça por parte do público ao qual se destinava a "mensagem" sartriana nela contida, mas não invalida a estratégia aí adotada, suscitando discussões fecundas em torno da "literariedade" dos conteúdos dramáticos veiculados por Sartre: "É suficiente ler os três primeiros textos deste terceiro período, Lexistentialisme est un humanisme, Les chemins de la liberté e sobretudo Les mouches cuja situação geral (Argos e a cerimônia do remorso) é uma transposição mal dissimulada da França sob Pétain". ${ }^{5}$

Segundo Francis Jeanson, a peça Les mouches deve ser compreendida, por um lado como uma denúncia da política de Vichy e dos discursos de Pétain, conclamando os franceses a expurgarem suas culpas a fim de melhor se resignarem com a ocupação alemã; por outro, como o tratamento da relação do homem com a sua liberdade. A este respeito é importante atentar às declarações do próprio Sartre:

Nós estávamos em 1943 e Vichy queria nos enterrar no arrependimento e na vergonha. Escrevendo Les mouches, eu tentei contribuir com meus próprios meios para extirpar um pouco esta doença do arrependimento, este abandono à vergonha que nos solicitavam. Era preciso então reerguer o povo francês, dar-lhe coragem. Oreste é o pequeno grupo de Franceses que cometeram atentados contra os Alemães e carregaram em seguida a angústia do arrependimento, esta tentação de ir se entregar. Por que fazer declamar os Gregos... se não for para disfarçar o pensamento sob um regime fascista?... O verdadeiro drama, aquele que eu gostaria de ter escrito, é o do terrorista que, matando Alemães na rua, desencadeia a execução de cinqüenta reféns. ${ }^{6}$

Foram os acontecimentos históricos que levaram Sartre à renúncia de um certo "amoralismo", sacramentado por ocasião da publicação de Lêtre et le néant, e a fundamentar uma filosofia, que pensa a libertação do homem pelo engajamento, como uma forma de dar sentido à existência. Solidificam-se, assim, as bases do seu já referido "moralismo", agora não mais alheio a um certo maniqueísmo.

\footnotetext{
${ }^{5}$ GOLDMANN. Structures mentales et création culturelle, p.210.

${ }^{6}$ Coletânea de entrevistas e publicações de Sartre, reunida por JEanson. Sartre dans sa vie, p.139-140.
} 
O duplo crime: o assassinato de Clytemnestre é Égisthe

O assassinato de Clitemnestra e Egisto é estruturado de forma diferenciada nas versões gregas. Sartre, na composição de Les mouches, recupera, com originalidade, determinados momentos que dotam sua peça de nova significação. A forma esquemática parece melhor evidenciar os pontos de convergência e divergência entre os gregos, conforme verifica-se a seguir.

ÉSQUILO

a) Presença dos sonhos premonitórios de Clitemnestra.

b) Estratégia estabelecida pelo s e g r e d o: disfarce de Pílades e Orestes como estrangeiros.

c) Electra pede ajuda ao Coro das Coéforas.

d) Pílades, ante a hesitação de Orestes, incita-o ao matricídio, lembrando os juramentos de Lóxias.

e) Co-adjuvação do crime: Pílades, Lóxias, a ama (que pede a Egisto que venha receber os "estrangeiros" sem escolta).

f) Egisto é assassinado primeiro. A cena não é descrita, assim como a do assassinato da rainha.

g) Orestes não se arrepende do matricídio.

h) com a chegada das Erínias, Orestes foge alucinado.

\section{SÓFOCLES}

a) Presença dos sonhos premonitórios de Clitemnestra.

b) Estratégia estabelecida pela mentira: o Preceptor descreve a morte de Orestes num concurso de cavalos velozes.

c) Electra clama pela Erínia.

d) Pílades lembra o momento de pedir proteção aos deuses e Electra participa do plano incitando Orestes a apunhalar a mãe.

e) Co-adjuvantes: Electra, Preceptor, Pílades.

f) A rainha é abatida primeiro. A cena é parcialmente descrita. Egisto também é justiciado por Orestes em cena não descrita.

g) Os irmãos arrependem-se do matricídio.

h) Orestes não é perseguido pelas Erínias.

\section{EURIPEDES}

a) Ausência dos sonhos premonitórios de Clitemnestra

b) Estratégia estabelecida através da mentira: Electra manda dizer à mãe que dera à luz para que esta venha vê-la e seja executada.

c) Electra clama por Jupiter.

d) O Velho (e não o oráculo) lembra que é preciso que os reis criminosos pereçam. Electra incita Orestes ao matricídio.

e) Co-adjuvantes: o Velho e Electra (morte de Clitemnestra); o Velho (morte de Egisto). 
f) A rainha é morta pelos dois filhos nesta versão.

g) Electra e Orestes se arrependem do matricídio.

h) Electra é dada como esposa a Pílades. Aconselhado pelos Dióscuros, Orestes segue para Atenas para pedir proteção a Palas (deusa Atená) contra as Erínias.

A preparação para o crime é transformada por Sartre pela derrisão, denunciada pelo diálogo entre os guardas do palácio real, enquanto Électre e Oreste se escondem atrás do trono, numa típica cena molieresca. No momento em que Oreste e Électre se movimentam atrás do trono, fazendo um rumor, os soldados acreditam ser o rei: "C'est Agamemnon: il doit être assis sur ses coussins: droit comme un I - et il nous regarde $[\ldots]$ nous ferions mieux de rectifier la position." $(\mathrm{M}, \mathrm{II} / 2,2)^{7}$

O diálogo cômico/absurdo é manifestado ainda de forma mais profunda, desta vez, seguindo os "moldes" de Ionesco: um soldado esbofeteia o outro e esclarece: "c'est pour ton bien; regarde, j'en ai tué sept d'un coup, tout un essaim". "Des morts?" indaga o $2^{\circ}$ soldado "non. Des mouches...J'ai du sang plein les mains". (M,II/2,2)

Em seguida, a imagem das moscas "mort-nées" é associada aos homens mortos de Argos, remetendo a uma idéia de "homens-vampiros": "ils se mangent les sangs, ces hommes-là". Esta movimentação, implementada por Sartre, anuncia a chegada de Égisthe e Clytemnestre, (cujos sonhos premonitórios não têm espaço na perspectiva existencialista), para o diálogo final.

\section{ÉGISTHE E O SENTIMENTO DO VAZIO}

Égisthe, braço forte do poder divino na terra, começa a dar indícios de cansaço: "je suis las. Voici quinze ans que je m'habille comme un épouvantail": (M,II/2,3). Ele revela também, pela primeira vez, seus sentimentos: "personne d'Argos n'est aussi triste que moi", diante de uma Clytemnestre que o chama à razão: "Est-ce que vous avez oublié que vous-même vous inventâtes ces fables pour le peuple?". Estas reflexões antecipam o monólogo em que Égishe mergulha na náusea sartriana, ao pensar no absurdo da condição humana:

Je suis une coque vide: une bête m'a mangé le dedans sans que je m'aperçoive. À présent, je regarde en moi-même, et je vois que je suis plus mort qu'Agamemnon. Aije dit que j'étais triste? J'ai menti. Il n'est ni triste ni gai, le désert, l'innombrable néant des sables sous le néant lucide du ciel: il est sinistre. Ah! je donnerais mon royaume pour verser une larme! $(\mathrm{M}, \mathrm{II} / 2,4)$

A "experiência do vazio", denunciada por "coque vide", é também experiência do nada; do ser fragmentado que desliza, numa sucessão de angústias, até a sua morte. No plano filosófico, só através da consciência o "nada", produto da "experiência do vazio", tem o poder de vir ao mundo, arrebatando consigo a eterna luta do "pour-soi" e "en-soi", que conduzirá à cisão final entre Jupiter e Égisthe.

\footnotetext{
${ }^{7}$ No corpo deste trabalho, as citações textuais de Les mouches serão indicadas pela inicial $\mathrm{M}$, seguida, em algarismo romano, do número do ato e, em arábico, da cena a que se referem.
} 
Égisthe: UM EStranho NO ESPELHO

Após a evocação de Égisthe: "Est-ce là, Jupiter, le roi dont tu avais besoin pour Argos?", o deus apresenta-se em "carne e osso", na mais completa desmistificação do sobrenatural:

"Tu ne me reconnais pas? Tu m'as vu pourtant. C'était en songe". "Jupiter!" "Nous y voilà!". Aproximando-se da estátua: "C'est ainsi qu'ils me voient quand ils prient, les habitants d'Argos? Parbleu, il est rare qu'un Dieu puisse contempler son image face à face" $(M, I I / 2,5)$.

A questāo da imagem, cara a este personagem, na medida em que reflete a petrificação do "en-soi", também preocupa Égisthe no plano político: "Depuis que je règne tous mes actes et toutes mes paroles visent à composer mon image [...] Mais c'est moi qui suis ma première victime: je ne me vois plus que comme ils me voient". (M,II/2,5)

Imagem, do latim imago, significa etimologicamente representaçāo, retrato, imitação, espelho, estátua. Égisthe colou-se de tal forma à representação dele mesmo que acabou petrificando-se, tornando-se, como Jupiter, estátua. Daí sua afirmação: "tous ces vêtements noirs ont fini par déteindre sur mon âme". ( $M, I I / 2,3)$

Se esta condição agora faz sofrer, por outro lado, traz algumas vantagens. É o que Jupiter anuncia a Égisthe: "Moi aussi, j'ai mon image. Crois-tu qu'elle ne me donne pas le vertige? [...] il faut qu'ils (les hommes) me regardent: tant qu'ils ont les yeux fixés sur moi, ils oublient de regarder en eux-mêmes". (M,II/2,5).

Desviando o olhar dos homens deles mesmos, mantendo-os alienados, a ordem e o poder estão salvaguardados, como confirma Jupiter: "Tu me hais, mais nous sommes parents. Je t'ai fait à mon image". Com esta frase, Sartre marca a derrisão do Gênese, que esclarece que Deus fez o homem à sua imagem e semelhança. Jupiter prossegue: "un roi c'est un Dieu sur la terre, noble et sinistre comme un Dieu". (M,II/2,5)

O tema da "imagem" liga-se também a espelho, na representação de lugar onde alguém se vê. No espelho vige o espaço da ambivalência do texto. Se por um lado, configura o "imaginário" da manifestação discursiva, na medida em que reproduz a imagem do que se (lê) vê, por outro, é o espaço que guarda a possibilidade de sentidos que escapam à evidência do código e que precisam ser desvelados.

Imagem liga-se a imaginário e ilusão. A importância que Égisthe atribui à representação de sua imagem cristalizada marca a tentativa de fuga do sujeito de si próprio, em direção a algo que lhe é exterior. Fuga de uma responsabilidade que inexoravelmente lhe pertence: a de justificar, pela soma de seus atos, a existência. Fuga para um lá que esbarra no "olhar do outro", que funciona ao mesmo tempo como "consciência observante" e objeto da consciência do outro.

É neste circuito onde o indivíduo se encontra preso entre o advento da consciência e a formulação da própria imagem, que se define a dimensão trágica do homem no mundo moderno.

\section{A cisão égisthe-Jupiter (Precipitaçāo do crime)}

Jupiter revela a Égisthe que alguém tentará matá-lo: Électre e também Oreste. O deus tenta desesperadamente convencer o rei a livrar-se da ameaça: "qu'on le (Oreste) jette avec Électre dans quelque basse-fosse". Diante da resistência do rei, 
("je vous dis que je ne veux pas entrer dans vos desseins. J'en ai trop fait"), Jupiter é forçado a revelar o que até então mantinha sob a forma de segredo: "le premier crime, c'est moi qui l'ai commis en créant les hommes mortels". (M,II/2,5)

A condição humana, limitada pela morte, deve buscar sua dignidade em si mesma, uma vez que é vitimada, na origem, pelo abismo que a separa do anseio comum de imortalidade e deste primeiro "crime", nasce a solidariedade dos homens entre si. A frase de Jupiter pode ser também confrontada com o livro do Gênese, onde se verifica que o primeiro pecado tornou os homens mortais. Aqui, eles o são por obra e graça do próprio deus, que os criou assim, voluntariamente.

Jupiter revela por que o crime dos homens lhe interessa: "C'est parce que tu l'expies qu'il me sert; j'aime les crimes qui paient". Do crime de Égisthe ("un meurtre aveugle et sourd"), resultou um saldo positivo para o deus: "pour un homme mort,vingt mille autres plongés dans la repentance, voilà le bilan". Face à atual resistência de Égisthe, Jupiter, confiante de sua força, diz: "Courage! Résiste! Ah! Que je suis friand d'âmes comme la tienne [...] mais cependant petite tête, petit cheval, mauvais petit cheval, il y a beau temps que ton coeur m'a dit oui. Allons, tu obéiras" $(M, I L / 2,5)$.

Para convencer Égisthe, o segundo grande segredo do deus deve ser revelado: o assassinato tem que ser evitado pois Oreste não terá remorsos:

Qu'ai-je à faire d'un meurtre insolent, d'un meurtre paisible, léger comme une vapeur dans l'âme d'un meurtrier? Je t'ai dit que tu es fait à mon image. Nous faisons tous les deux régner l'ordre, toi dans Argos, moi dans le monde, et le même secret pèse lourdement dans nos coeurs [...] le secret douloureux des Dieux et des rois. C'est que les hommes sont libres. Ils sont libres, Égisthe. Tu le sais, et ils ne le savent pas. (M,II/2,5)

E para que os homens não descubram tal segredo, o deus deve esforçar-se: "Depuis cent mille ans je danse devant les hommes. Une lente et sombre danse". A dança de Jupiter metaforiza o seqüestro da liberdade dos homens pela alienação.

A associação "Égisthe-cheval", feita por Jupiter, parece enfatizar as características de montaria deste animal, quando domesticado e dócil ao comando do seu dono e senhor. É comum, em muitas religiōes, sobretudo orientais, (por exemplo o hinduísmo), a associação do deus com o animal que lhe serve de montaria. Neste contexto, podemos lembrar que, no candomblé, é dita "cavalo" a pessoa que incorpora uma entidade. De qualquer modo, para que sirva bem ao seu senhor, o cavalo não deve ser resistente às ordens dadas, sem o que se tornaria um "mauvais (petit) cheval", onde o "petit", se carinhoso e afetivo, pode rebelar-se, denunciando a diferença hierárquica entre os implicados, camuflada por um logro, como o verificado na história do "cavalo de Tróia".

A revelação do segredo dos deuses possui desdobramentos. À afirmação de Jupiter — "Oreste sait qu'il est libre" - Égisthe retruca, solicitando providências: "Dieu tout-puissant, qu'attends-tu pour le foudroyer?". É então que o maior de todos os segredos divinos é revelado:

Jupiter: Égisthe, les Dieux ont un autre secret... quand une fois la liberté a explosé dans une âme d'homme, les Dieux ne peuvent plus rien contre cet homme-là. Car c'est aux autres hommes - à eux seuls — qu'il appartient de le laisser courir ou de l'étrangler. $(\mathrm{M}, \mathrm{II} / 2,5)$ 
O assassinato de ÉgISthe

Électre, num primeiro momento, participa do plano de assassinato de Égisthe. A Oreste: "Frappe-le! Ne lui laisse pas le temps de crier; je barricade la porte". Enquanto Égisthe, já mergulhado na crise existencial, oscila mais fortemente entre a manutenção da imagem criada (en-soi) e a possibilidade de pela primeira vez exercer sua liberdade (pour-soi), deixando-se abater por Oreste, assumindo assim as rédeas de seu destino.

Do conflito angustiado entre o homem consciente e o rei instrumentalizado, o primeiro sai vitorioso: "Je ne me défendrai pas. Il est trop tard pour que j'appelle et je veux que tu m'assassines" (M,II/2,6).

A significação deste crime, em confronto com as versões gregas, é totalmente nova. Se para aquelas representava a "vingança" ditada pelos deuses, indicando que os que mataram deveriam morrer, agora reveste-se de um sentimento fundado na dignidade da condiçāo humana, na busca de um sentido humano de justiça. Por isso, diz Oreste: "La justice est une affaire d'hommes et je n'ai pas besoin d'un Dieu pour me l'enseigner. Il est juste de ruiner ton empire sur le gens d'Argos, il est juste de leur rendre le sentiment de leur dignité". (M,II/2,6)

Um segundo golpe desfechado contra Égisthe reforça a determinaçāo de Oreste em fazer seu ato, através da morte do assassino e tirano: "Tu n'en finiras donc pas, de mourir? (il le frappe. Égisthe tombe)". As últimas palavras de Égisthe chamam a atenção de Oreste para a presença das moscas: "tout n'est pas fini". Oreste, contudo, já em acordo com a proposta existencialista que concebe a morte como o ponto final da existência individual, conclui: "pour lui, tout est fini en tout cas".

\section{A tENSÄO LUZ/TREVAS}

A presença das Erínias entre os gregos era associada à escuridão, pois as "trevas da noite" eram clamadas sob escombros do palácio: "impenetráveis ao sol [...] odiadas pelos mortais, as trevas ocultam as casas cujos donos morreram", anuncia o Coro das Coéforas.

O duplo assassinato implicava lá uma preparação para a luz: "agora é possível ver a luz [...] as Estrangeiras (as Erínias) serão de novo expulsas do palácio", (Ésquilo, 1976 , p. 70). Sartre reutiliza-se desta perspectiva grega ao defini-las como "les filles de la nuit" ou, segundo Électre, como "chiennes noires". Para o autor, porém, só não vê a luz quem não quer. Por isso Oreste enfrenta uma Électre fraca.

Électre, derrière cette porte, il y a le monde et le matin. Dehors, le soleil se lève sur les routes ensoleillées, et ces filles de la nuit perdront leur puissance: les rayons du jour les transperceront comme des épées. Ne pense pas à elles. Elle ne peuvent rien contre toi [...] C'est ta faiblesse qui fait leur force. $(M, I I I, 1)$

Oreste anuncia a luz, em oposição às trevas que envolvem a atuação de Électre, aterrorizando-a, e revela a terceira função que pode ser atribuída às Erínias: marcar definitivamente a cisão entre os irmãos. Por isso, ele declara: "une horreur sans nom s'est posée sur toi et nous sépare". (M,III,1)

A oposição claro $\mathrm{x}$ escuro, luz $\mathrm{x}$ trevas, implicará o aparecimento de outra que reforçará esta cisão: juventude $\mathrm{x}$ velhice. Diz a terceira Erínia: "Oreste est presque 
un enfant. Ma haine aura pour lui des douceurs maternelles". (M,III,1). Em seguida, Électre confessará: "J'ai vieilli en une nuit", para assumir o papel de Clytemnestre, reforçado pela semelhança existente entre ambas. Oreste: "tu es encore belle, mais... où donc ai-je vu ces yeux morts? Électre...tu lui ressembles; tu ressembles à Clytemnestre". (M,III, 1)

\section{ERINIAS: METÁFORA DO SANGUE}

A imagem sangrenta torna-se metafórica em Sartre. Para Électre, esta imagem provoca o medo: "Tu me fais peur. J'ai rêvé que notre mère était tombée à la renverse et qu'elle saignait, et son sang coulait en rigoles sous toutes les portes du palais. [...] Est-ce qu'elle a beaucoup saigné?" (M,III,1). Mesmo as Erínias rechaçam esta imagem indesejável: "Chasse-le, Électre, [...] c'est un boucher! il a sur lui la fade odeur du sang frais", e, gritando, injuriam: "Bourreau, Bourreau, Boucher!".

Dentre as qualidades atribuídas aos heróis, atacadas no ritual de dança implementado pelas Erínias, também a imagem sangrenta é referida: "Bzz, bzz, bzz, bzz. Nous nous poserons sur ton coeur pourri comme des mouches sur une tartine, coeur pourri, coeur saigneux, coeur délectable". (M,III,1)

Todas essas referências parecem confluir para a origem mítica do nascimento das Erínias. A versão tradicional explica que elas são filhas da Terra (Gaia). Por ter jogado os filhos, os Cíclopes, no Tártaro, Uranos foi castrado pelo seu filho Cronos, sob a ordem de Gaia. Cronos jogou os órgãos genitais e a foice, instrumento da castração, no mar. Mas, das gotas de sangue, caídas no solo da Terra-Mãe, nasceram três Erínias: Alecto, Tisifonê e Megera.

A versāo de Ésquilo, que anuncia furiosos ataques das Erínias, atraídas pelo sangue do rei, também confirma esta relaçāo. Através da metáfora do sangue pode ser revelada a cumplicidade que identifica as Erínias às Moscas: "Dizem que estes insetos (as moscas), derrubados pela queda brusca do barômetro, têm necessidade de se refrescar, absorvendo, aliás, uma bebida muito nutritiva - nosso sangue". ${ }^{8}$

\section{ORESTE-JUPITER: A CISÃo FINAL}

A seqüência de cisões ocorridas ao longo da peça, (Jupiter/Égisthe; Électre/ Oreste), culmina com o confronto final (Oreste/Jupiter), fundamental para a exposição da filosofia sartriana. Demonstramos esta cisāo, de forma esquemática, através de diálogos (confrontos) entre estes personagens.

\section{Jupiter}

Regarde-toi, créature impudente et stupide [...] si tu oses prétendre que tu es libre, alors il faudra vanter la liberté du prisonnier chargé de chaînes, au fond d'un cachot, et de l'esclave crucifié.

\section{Oreste}

Pourquoi pas?

\footnotetext{
${ }^{8}$ W ATHELET. Dictions de bêtes, des plantes et des saisons, p.89-90.
} 
Identificamos, através da resposta de Oreste, uma intercomunicação com o humanismo de Camus, onde a imagem do "prisonnier chargé de chaînes" corresponderia ao mito de Sísifo feliz. Sísifo encontra no ato, aparentemente gratuito, ao qual fora condenado - rolar incessantemente uma rocha até o cume de uma montanha, de onde a pedra caía pelo seu próprio peso - um sentido existencial. Ao fazê-lo, Sísifo empresta ao ato sua revolta e sua paixão, no exercício pleno da liberdade. É este fato que Sartre parece evocar, ao reconhecer a liberdade possível mesmo ao "esclave crucifié". A passagem, lembrando o Cristo-deus-humanizado, remete também às imagens pascalianas da condição humana, onde homens acorrentados, condenados à morte, eram executados à vista de outros condenados, que viam sua própria condição na de seus semelhantes.

\section{Jupiter}

Sais-tu ce qu'il y a derrière cette porte? Les hommes d'Argos [...] ils attendent leur sauveur avec des pierres, des fourches et des triques. Tu es seul comme un lépreux [...] c'est dans la solitude du mépris et de l'horreur qu'ils t'ont rejeté, ô le plus lâche des assassins.

\section{Oreste}

Le plus lâche des assassins, c'est celui qui a des remords.

O tema da lepra, abordado pelos gregos, reaparece também em Les mouches. Em Ésquilo, Lóxias ameaçara Orestes de castigos terríveis se ele não cumprisse suas determinações: "Senão, afirmou ele, eu mesmo pagaria com a vida, entre inúmeros e cruciantes tormentos [...] ele nos deu a conhecer as temíveis doenças que assaltam as carnes, as lepras que devoram, com maxilas selvagens, aquilo que antes era um corpo".

Este dado é retomado por Sartre para delinear a feição solitária do herói. Por isso, Jupiter insiste: "Tu es seul comme un lépreux [...] dois-je admirer la brebis que la gale retranche du troupeau, ou le lépreux enfermé dans son lazaret? [...] ta liberté n'est qu'une gale qui te démange, elle n'est qu'un exil" $(M, I I I, 2)$. Ao que Oreste retruca: "Tu dis vrai: un exil". Para Sartre, liberdade é exílio à medida que apenas o indivíduo é capaz de exercê-la em seu próprio nome. Mas, paradoxalmente, é este exílio que concede a Oreste a possibilidade de Ser: "Je ne suis ni le maître, ni l'esclave, Jupiter. Je suis ma liberté!".

Ao buscar o caminho do meio, mais compatível com a medida do homem, linitado pela sua condição, Sartre, novamente, toca no humanismo de Montaigne, já resgatado por Camus. Diz o Doutor Rieux, personagem de La Peste: "Eu não tenho tendências, acredito, nem para o heroísmo nem para a santidade, o que me interessa é ser homem". ${ }^{10}$

${ }^{9}$ ÉsQuilo. Oréstia, p.55.

${ }^{10}$ Camus. La peste, p. 230. 
É porém o próprio Sartre quem, referindo-se ao período da ocupação nazista, em Paris, esclarece o ponto:

Mas não podíamos achar natural sermos homens quando nossos melhores amigos [...] só podiam optar entre a abjeção e o heroísmo, quer dizer entre os dois extremos da condição humana, além do que não há mais nada. Covardes e traidores, eles tinham sobre eles todos os homens, heróis, todos os homens abaixo deles. ${ }^{.1}$

Oreste, tomado por uma lucidez que reflete o próprio conceito de "luz" para Sartre, assume sua liberdade em plenitude, e acusa Jupiter: "tu es le roi des Dieux, Jupiter, le roi des pierres et des étoiles, le roi des vagues et de la mer. Mais tu n'es pas le roi des hommes." (M,III,2).

Dizendo isto, Oreste atribui ao deus apenas a responsabilidade na criação do mundo natural: "pierres", "étoiles", "vagues", "mer", mundo objetivo ou, segundo F. Mueller, "dado bruto", reflexo do "en-soi". O elemento subjetivo, a "criação humana", contudo, tem, a partir desta afirmação, sua paternidade à deriva. Relembrando a célebre frase de Sartre de que o homem é o único ser em que a existência precede a essência, Oreste veicula literariamente a perspectiva filosófica do autor.

\section{DESFECHO DA TRAMA}

Oreste permanece só com as Erínias, após a derrocada de Électre:

Au secours! Jupiter roi des Dieux et des hommes, mon roi, prends-moi dans tes bras, emporte-moi, protège-moi. Je suivrai ta loi, je serai ton esclave et ta chose [...] défendsmoi contre les mouches, contre mon frère, contre moi-même $[. .$.$] je consacrerai la vie$ entière à l'expiation. Je me repens. Jupiter, je me repens. (Elle sort en courant). (M,III,3)

percurso de Électre, em Sartre, pode ser aproximado do seu homônimo em Eurípedes, onde ela mergulha no arrependimento, após o assassinato dos reis. Aqui, esta brusca reviravolta pode assumir uma conotação política, sendo interpretada como uma denúncia contra a tentação que acometia os franceses que praticavam atentados contra os alemães, de em seguida irem se entregar.

Há uma tentativa inicial das Erínias de seguir Électre. Contudo, a primeira Erínia interfere: "Laissez-la, [...] elle nous échappe. Mais celui-ci [Oreste] nous reste [...] il souffrira pour deux" $(M, I I I, 4)$. Surge então o Pédagogue, cuja presença precipitará o desfecho do drama: "Ça, mon maître, où êtes-vous? On n'y voit goutte [...] les gens d'Argos assiègent le temple, et vous ne pouvez songer à en sortir". (M,III,5)

A decisão de Oreste é entretanto surpreendente: "c'est bon [...] ouvre cette porte". Oreste coloca-se, então, diante da multidão enfurecida. Sua primeira exclamação: "Le soleil!" (M,III,6), marcando uma aproximação com os gregos, que assim concluíam suas tragédias, (em oposição à escuridão existente dentro do palácio) mostra que para Sartre a claridade é uma luz interior que se acende.

A presença do sol, que anuncia este desfecho iminente, já iniciara a peça Representando o juiz vigilante que tudo vê, o Sol (=Apolo) sempre ester: miticamente ligado a Deus. Ele é o olho divino que faz aparecer a Verdade, encobert.

\footnotetext{
"SARTRE. Situations II, p.249-250.
} 
pelas trevas. Sartre utiliza-se desta simbologia para revelar duas verdades: a de Oreste, marcada pela assunção de seu ato e possíveis conseqüências; a do povo, diante de quem o herói se coloca, e que a luz do sol permite inserir dentro da definição sartriana de "lâche" (=covarde). Oreste assume definitivamente seu ato, agora diante da multidão de argivos:

Vous voilà donc, mes sujets très fidèles! Je suis Oreste, votre roi, le fils d'Agamemnon, et ce jour est le jour de mon couronnement [...] il y a quinze ans [...] un autre meurtrier s'est dressé devant vous [...] vous n'avez pas eu peur de lui car vous avez lu dans ses yeux qu'il était des vôtres et qu'il n'avait pas le courage de ses actes. Un crime que son auteur ne peut supporter, ce n'est plus le crime de personne [...] c'est presque un accident. (M,III,6)

Dizendo isto, Oreste estabelece a diferença entre o significado do seu crime e o de Égisthe. O de Oreste, (compreendido como sua luz), é reivindicado diante do sol:

Vous avez compris que mon crime est bien à moi; je le revendique à la face du soleil, il est ma raison de vivre et mon orgueil, vous ne pouvez ni me châtier ni me plaindre et c'est pourquoi je vous fais peur. Et pourtant, ô mes hommes, je vous aime, et c'est pour vous que j'ai tué. $(\mathrm{M}, I I I, 6)$.

A afirmação final de Oreste tem significado ambíguo. Se o herói praticou seu ato enquanto homem livre, numa atitude solitária, (ainda que solidariamente marcada pelo engajamento, que o faz sentir-se "homem entre os homens"), parece incoerente a afirmação "c'est pour vous que j'ai tué", fazendo eco ao cordeiro de Deus que tira os pecados do mundo. Por isso, a ambigüidade assume uma força tamanha que é capaz de transformar o tão propalado ato de Oreste num gesto espetacular. $O$ que ele deseja é atrair a atenção da multidão de espectadores sobre sua ação.

$\mathrm{Na}$ realidade, como ocorrera com Électre, de modo mais radical, Oreste também dá, de uma certa forma, uma guinada, modificando o seu propósito inicial. Ele busca agora uma alternativa individual e não uma liberação prática, que só poderia ser alcançada com o consentimento dos argivos. De modo contrário, Oreste estaria destruindo, para posteriormente reabilitar, Jupiter e Égisthe, negando o próprio existencialismo.

Sartre, com maestria, situa cuidadosamente a ação do herói neste tênue limite que é a linha divisória da liberdade que vai do Eu ao Outro. Também, com este desfecho ambíguo, ele mostra que:

A liberdade como definição do homem nāo depende dele, mas a partir do momento em que há o engajamento, eu sou obrigado a querer ao mesmo tempo que minha liberdade a liberdade dos outros. Eu não posso assumir minha liberdade como fim se não assumir igualmente a dos outros como tal. ${ }^{12}$

A cena reflete, mais uma vez, a importância do "olhar". Ao mostrar-se à luz do sol, Oreste faz-se objeto do olhar do Outro, ao mesmo tempo em que, olhando-o também à luz do sol, fixa este Outro como objeto, num circuito interminável de subjetividades. Por isso, Sartre concluirá: "o Outro é a morte escondida das minhas possibilidades."13

\footnotetext{
"SARTRE. L'existencialisme est un humanisme, p.83.

${ }^{13}$ SARTRE. L'être et le néant, p.323.
} 
Desta relação Eu/Outro, nasce um conflito, pois sou alienado pelo Outro do mesmo modo que o alieno, logo sou eternamente insatisfeito no meu desejo de reconhecimento, já que é impossível que uma consciência apareça a outra como consciência. $O$ ser consciência exclui radicalmente qualquer objetividade, porque ser objeto para uma consciência é não mais ser consciência. $O$ ato passa a ter finalidade apenas em si próprio, (momento privilegiado ou pura ilusão fugaz), não resolvendo a grande questão da eterna busca, destinada a permanecer para sempre sem respostas. Oreste traz para si a responsabilidade que pesa sobre os argivos:

Vos fautes et vos remords, vos angoisses nocturncs, le crime d'Égisthe, tout est à moi, je prends tout sur moi. Ne craignez plus vos morts; ce sont mes morts. Et voyez: vos mouches fidèles vous ont quitté pour moi. Mais [...] je ne m'assiérai pas, tout sanglant, sur le trône de ma victime: un Dieu me l'a offert et j'ai dit non. Je veux être un roi sans terre et sans sujets. Adieu mes hommes. Tentez de vivre: tout est neuf ici, tout est à conmencer. Pour moi aussi la vie commence. Une étrange vie. $(\mathrm{M}, \mathrm{III}, 6)$

O povo argivo não reconhece Oreste como seu libertador, justamente porque este povo não é o Destinador da missão a que Oreste se propōe. É antes, ele mesmo, também destinatário de uma liberdade plena que, ao contrário do herói, nāo assumiu como sua. Destinatário desqualificado, portanto.

A ambigüidade que observamos neste desfecho iminente, pressentida em todo o texto, remete à concepção de Sartre de que Les mouches, sendo uma obra de Resistência, deveria fundar-se numa significação ambígua. "Nós nos persuadíamos [...] pensando neste período, que nenhuma arte seria verdadeiramente nossa se não dotasse o acontecimento de [...] sua ambigüidade, sua imprevisibilidade."14

É neste clima de inovação total que Oreste encerra sua participação na peça, substituindo o "tocador de flauta" de Hemlim pelo "joueur de flûte" de Skyros, com quem se identifica na cena final:

Écoutez encore ceci: un été Scyros fut infestée par les rats. C'était une horrible lèpre [...] ils rongeaient tout; les habitants de la ville crurent en mourir. mais un jour, vint un joueur de flûte. Il se dressa au coeur de la ville — comme ceci (il se met debout). Il se mit à jouer de la flûte et tous les rats vinrent se presser autour de lui $(\mathrm{M}, \mathrm{III}, 6)$.

Do ponto de vista filosófico, também nāo é gratuita a ambigüidade que se observa nesta solução. Lucien Goldmann a resolve afirmando que, mais cedo ou mais tarde, qualquer "pour-soi"- - ser da liberdade - mesmo o mais consciente e mais livre, transforma-se em "en-soi" - ser do mundo petrificado - uma vez que os atos livres são todos provisórios, já que limitados pela barreira inexorável da morte.

Por isso, agora, o Logos vai substituir a Práxis, pois Oreste desvia-se da ação e passa a fascinar pela palavra, utilizando-se, para tal, de uma fábula, como se este ato bastasse para que ele justificasse eternamente o ser Oreste. Neste momento ele anuncia-se "en-soi". Sartre, ao contrário, em sua filosofia, revela que o homem não é "ensoi", mas "pour-soi", "néantisation" permanente do ser, transcendência perpétua. O homem é o que não é (ainda) e não é mais o que ele é (já). Destarte, o dilema de Oreste coloca em cena o dilema do próprio Sartre: servir-se da palavra e não da ação,

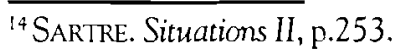


procurando o quase impossível equilíbrio entre seu instinto revolucionário e sua formação intelectual burguesa.

\section{CONCLUSÄO}

A abordagem semiológica e comparativista, que norteou o presente estudo, evidenciou, na revitalização do mito grego de Orestes e Electra, "sentidos" outros que dotam Les mouches de nova significação.

Assim, o séc. XX incorpora o componente trágico para perpassá-lo com os problemas que afligem a época contemporânea, na qual a substância trágica ainda reside. Através da elaboração de Les mouches, em 1943, como uma parábola política, concebida no momento da ocupação nazista na França, Sartre dá sua contribuição à renovação mítica, associando a esta uma perspectiva sócio-histórico-filosófica.

A metodologia utilizada buscou evidenciar a originalidade da proposta sartriana, explicitada por uma dramaturgia que reflete, pelo viés da literatura, o engajamento do homem no seu tempo-espaço social, na sua situação histórica, no seu contexto político, denunciando a inexorabilidade de sua liberdade e responsabilidade totais face ao mundo no qual se acha inserido por pura contingência. 


\section{RÉ S U MÉ}

Proposition de lecture d'un'passage de la pièce de Sartre, Les mouches, fondée sur la méthode comparative, tout en établissant des rapports entre la version sartrienne du mythe de référence grec, d'Oreste et d'Electre, et celles developpées par les tragédiographes grecs, du $V^{c}$ siècle av. J.-C., Sophocle, Eschyle et Euripide. A partir de cette confrontation, on essayera de mettre en lumière l'originalité de la version sartrienne, transformée en fonction du moment socio-historique-politique actuel et de la philosophie existentialiste.

\section{MOTS - CLÉ S}

théâtre sartrien, tragédie, mythe grec

\section{REFERÊNCIAS BIBLIOGRÁFICAS}

Agulhon, Maurice, Schor, Ralph, Nouschi, André. La France de 1940 à nos jours. Paris, Nathan, 1988.

Barthes, Roland. Le plaisir du texte. Paris: Seuil, 1973.

Brunel, Pierre. Pour Électre. Paris: Armand Colin, 1982.

Camus, Albert. La peste. Paris: Gallimard, 1947.

Camus, Albert. Conférence prononcée à Athènes sur l'avenir de la tragédie. In: Camus, Albert. Théâtre, récits et nouvelles. Paris: Gallimard, 1962.

DomenaCH, Jean-Marie. Le retour du tragique. Paris: Seuil. 1967.

Ésquilo. Oréstia. Rio de Janeiro: Centro de Documentação e Letras da Universidade Santa Úrsula, 1976.

Eurf́pides. Electra, Alceste, Hipólito. Rio de Janeiro: Tecnoprint, s.d.

Goldmann, Lucien. Structures mentales et création culturelle. Paris: Antropos, 1970.

Jeanson, Francis. Sartre dans sa vie. Paris: Seuil, 1974.

Mueller, Fernand-Lucien. Lirrationalisme contemporain. Paris: Payot, 1970.

RomiLLY, Jacqueline de. La tragédie grecque. Paris: PUF, 1973.

Sartre, Jean-Paul. La nausée. Paris: Gallimard, 1938.

SARTRE, Jean-Paul. Lêtre et le néant. Paris: Gallimard, 1943.

Sartre, Jean-Paul. Lexistentialisme est un humanisme. Paris: Gallimard, 1946.

SARTRE, Jean-Paul. Huis clos suivi de Les mouches. Paris: Gallimard, 1947.

SARTRE, Jean-Paul. Situations II. Paris: Gallimard, 1948.

Sófocles. Electra. Trad. Irmã Maria da Eucaristia Daniellou. Rio de Janeiro: Associação Universitária Santa Úrsula - Faculdade de Filosofia, Ciência e Letras, 1975.

W ATHeLET, Jean-Marc. Dictons de bêtes, des plantes et des saisons. Le français retrouvé. vol.13. Paris: Librairie Eugène Belin, 1987. 